\title{
Assessment of Bird Species in Central Mindanao University, Bukidnon, Philippines
}

\author{
Geonyzl L. Alviola (corresponding Author) \\ Davao Doctors College, Gen. Malvar St., Davao City, \\ Philippines 8000, Email: geonyzlalviola27@gmail.com
}

\author{
Alma Mohagan \\ Central Mindanao University \\ Musuan, Maramag, Bukidnon
}

Received: June 14, 2017 Accepted: July 7, 2017 Published: July 28, 2017

doi:10.5296/jbls.v8i2.11395

URL: https://doi.org/10.5296/jbls.v8i2.11395

\begin{abstract}
Birds are important indicators to determine the quality of habitat. They played an important role in maintaining the balance of our ecosystem. This study aims to determine the species of birds and its diversity within the Central Mindanao University main campus. A line transect method combined with bird watching technique were used within the two month avian survey. A total of 27 species belonging to 21 families were recorded namely, Accipitridae, Alcedinidae, Apodidae, Ardeidae, Artamidae, Bucesotidae, Campephagidae, Columbidae, Corvidae, Dicaeidae, Estrildidae, Hirundiniidae, Laniidae, Meropidae, Nectariniidae, Phasianidae, Pycnonotidae, Sturnidae and Sylviidae. Out of the 27 bird species observed, 18 resident, 3 resident-migrant, 5 Philippine endemic and 1 island endemic. The most observed species are Euarasian Tree Sparrow (Passer montanus) and followed by an introduced species which was Feral Pigeon (Columba livia). Most of the species observed were commonly found in urban communities, agroecosystem and along the forest edge. Some species of birds belonging to family Nictariniidae and Dicaeidae are associated in areas with flowering trees and there are seldom observed in other points. The average diversity of all points $H^{\prime}=0.94$ which is quiet low and it requires more sampling effort and other technique to record silent or shy species.
\end{abstract}

Keywords: Bird survey, Bukidnon, Diversity, Birds 


\section{Introduction}

Birds are endothermic animals that serve as biological indicator in assessing the health of a habitat. They are widely distributed depending on the type of habitat preferences, availability of food items and season. This would affect their diversity and abundance within an area. According to McIntyre (1995), a change in landscape affects the ecological characteristics as species diversity and relative abundance. This made the birds an effective indicator in demonstrating the effects of landscape change. Bird assemblages in tropical agro forest ecosystems composed of disproportionately more frugivore and nectarivorous bird species compared with forest. Meanwhile the insectivorous species are associated to the forest habitats (Tscharntke et al., 2008). In agro ecosystems, the population of avian pollinators and seed dispersers during the flowering and fruiting seasons of plants and slowly declines in proportion in off season. Bird distribution patterns would also depend on the type for available food item within the area, but it depends on the forest fragment and edge pattern effects from adjacent, non-forest habitats (Barbaro et al, 2014). This study aimed to determine the bird species and its diversity in the area surrounded with a forest fragment and agro ecosystems.

\section{Research Methods}

\subsection{Sampling Site}

The avian survey was conducted in Central Mindanao University Main campus. It is located at $7.8593^{\circ} \mathrm{N}$ and $125.0500^{\circ} \mathrm{E}$. It has a total land area of 3,800 hectares, surrounded with residential communities, forest patches, and pasture land and agro ecosystems (see Figure 1). A line transect was used with corresponding observation points (O1-O4) see fig. 1. Observation area 1, composed of old growth mahogany trees lined along the path. Observation area 2, consist a large open area with a small pond and a forest patch. It consists of Pinus sp., old growth flowering trees and fruiting trees. Observation area 3 found in between the CMU Park and two forest fragment. The area is composed of old growth tree species like Mahogany, flowering trees and some herbaceous plants. Lastly the observation area 4, it is near the Mushroom Development Program, residential community and agricultural land. The vegetation is composed of grassland, some Mahogany tree species and Pinus sp.

\subsection{Avian Survey and Analysis}

In every point 15 minutes to 20 minutes were allotted for bird survey and 15 minutes allotted to transfer from one observation point to the other. A paired binocular was used to observe the birds and digital camera to document the birds found within the area. For identification, Field guide to Philippine birds by Kennedy et al. (2000) was used. Bird survey started from April to May of 2016 every 5:30 am to 9:00 am during high bird activity and in a fair weather condition. Diversity was computed using Biodiversity Pro to analyze the diversity of the species observed within the area. 


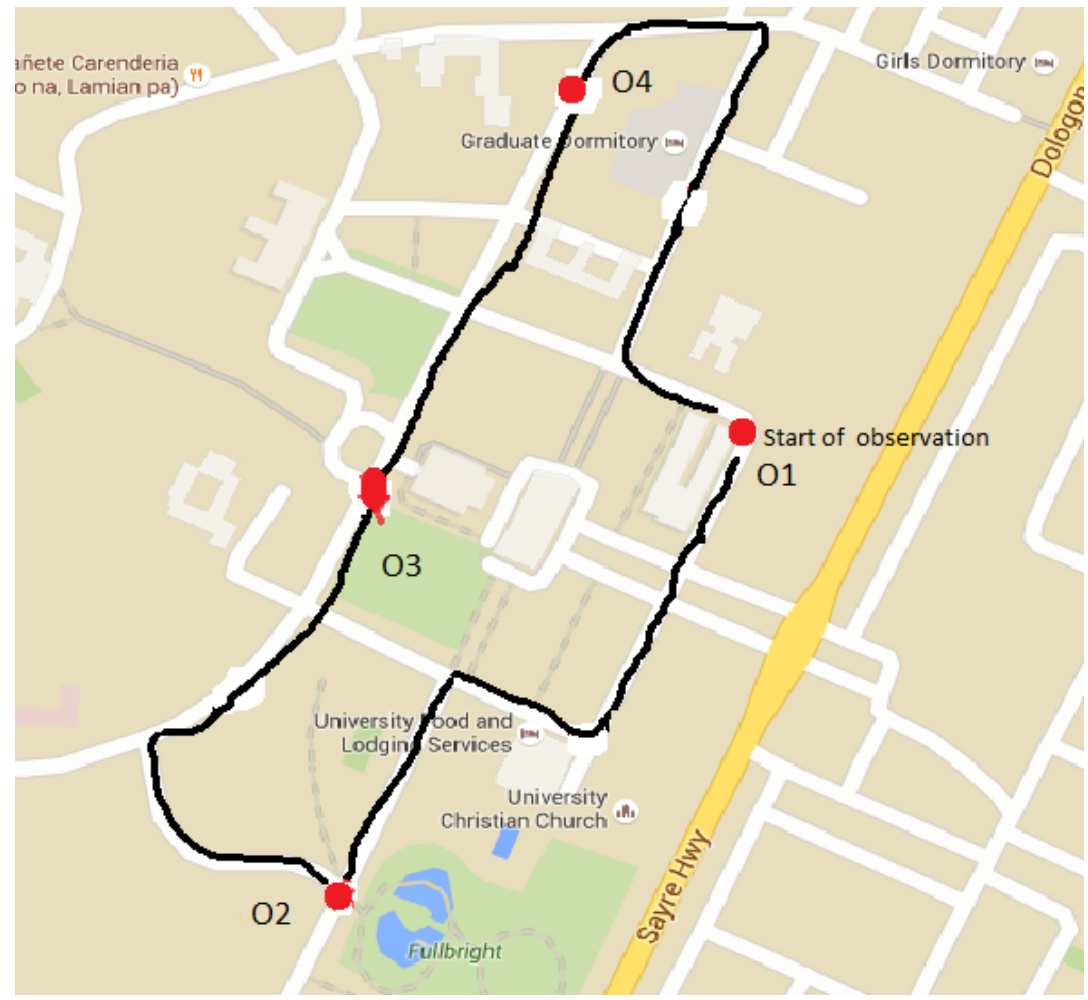

Figure 1. Location of the study site with observation points (O1-O4) (Google Earth, 2016).

\section{Results and Discussion}

There are 27 species of birds belonging to 21 families as shown in Table 1 and seen in Plate 1. Among the 27 birds 18 are resident, 3 resident-migrant, 5 Philippine endemic and 1 island endemic. The most abundant birds species observed in all area are Eurasian tree sparrow $(P$. montanus), Olive-backed Sunbird (Nectarinia jugularis), Yellow-vented Bulbul (Pycnonotus goiavier) and Pacific Swallow (Hirundo tahitica). These birds are likely associated to their food items, like Pacific Swallows (H. tahitica) is closely associated to abundance of insect prey (Turner, 1983). The role of bird-insect interaction would depend on forest fragmentation, edge effects from adjacent non-forest habitats (Barbaro et al, 2014) and weather (Turner, 1983).

Table1. Bird species observed within the CMU main campus in four observation areas.

\begin{tabular}{|l|l|l|l|l|l|l|}
\hline \multicolumn{1}{|c|}{ Family } & \multicolumn{1}{|c|}{ Name } & \multicolumn{1}{|c|}{ Status } & O1 & O2 & O3 & O4 \\
\hline Accipitridae & $\begin{array}{l}\text { Bhraminy Kite } \\
\text { (Haliastur } \text { indus })\end{array}$ & Resident - common & 3 & & \\
\hline Alcedinidae & $\begin{array}{l}\text { White Collared Kingfisher } \\
\text { (Halcyon chloris })\end{array}$ & Resident - common & 2 & 2 & 2 \\
\hline Apodidae & $\begin{array}{l}\text { Variable Dwarf Kingfisher } \\
\text { (Ceyx lepidus })\end{array}$ & $\begin{array}{l}\text { Min. Endemic - } \\
\text { uncommon } \\
\text { (Apus affinis })\end{array}$ & $\begin{array}{l}\text { Resident- locally } \\
\text { common }\end{array}$ & 5 & 1 & \\
\hline & Philippine Swiftlet & Endemic-common & 4 & 4 & & \\
\hline
\end{tabular}




\begin{tabular}{|c|c|c|c|c|c|c|}
\hline & (Collocalia mearnsi) & & & & & \\
\hline Ardeidae & $\begin{array}{l}\text { Cattle Egret } \\
\text { (Bubulcus ibis) }\end{array}$ & Resident - Migrant & & 3 & & \\
\hline Artamidae & $\begin{array}{l}\text { White Breasted Wood } \\
\text { Swallow } \\
\text { (Artamus leucorynchus) }\end{array}$ & Resident - common & & & & 7 \\
\hline Bucesotidae & $\begin{array}{l}\text { Tarictic Hornbill } \\
\text { (Penelopidus panini) }\end{array}$ & $\begin{array}{l}\text { Endemic }- \text { Fairly } \\
\text { Common }\end{array}$ & 3 & & & \\
\hline Campephagidae & $\begin{array}{l}\text { Pied Triller } \\
(\text { Lalage nigra })\end{array}$ & Resident- Common & & & 7 & \\
\hline \multirow[t]{4}{*}{ Columbidae } & $\begin{array}{l}\text { Feral Pigeon } \\
\text { (Columba livia) }\end{array}$ & Common & & & 70 & \\
\hline & $\begin{array}{l}\text { Reddish Cuckoo Dove } \\
\text { (Macropygia phasianella) }\end{array}$ & Resident - Common & 2 & & 3 & \\
\hline & $\begin{array}{l}\text { White-eared Brown Dove } \\
\text { (Phapiteron leucotis) }\end{array}$ & Endemic - Common & 1 & 3 & 2 & 5 \\
\hline & $\begin{array}{l}\text { Zebra Dove } \\
\text { (Geopelia striata) }\end{array}$ & Resident - Common & & 1 & 4 & \\
\hline Corvidae & $\begin{array}{l}\text { Slender Billed Crow } \\
(\text { Corvus enca })\end{array}$ & $\begin{array}{l}\text { Resident - Locally } \\
\text { Common }\end{array}$ & 1 & 6 & & 1 \\
\hline \multirow[t]{2}{*}{ Dicaeidae } & $\begin{array}{l}\text { Pgymy Flowerpecker } \\
\text { (Dicaeum pgymaeum) }\end{array}$ & Endemic- common & & 2 & & \\
\hline & $\begin{array}{l}\text { Red-keeled Flowerpecker } \\
\text { (Dicaeum australe) }\end{array}$ & Endemic-common & & 2 & & \\
\hline Estrildidae & $\begin{array}{l}\text { Chestnut Munia } \\
\text { (Lonchura malacca) }\end{array}$ & Resident - common & & 18 & 10 & 7 \\
\hline Hirundiniidae & $\begin{array}{l}\text { Pacific swallow } \\
\text { (Hirundo tahitica) }\end{array}$ & Resident - common & 10 & 12 & 8 & 5 \\
\hline Laniidae & $\begin{array}{l}\text { Brown Shrike } \\
\text { (Lanius cristatus) }\end{array}$ & Migrant - Common & & 3 & & \\
\hline Meropidae & $\begin{array}{l}\text { Blue-throated Bee-eater } \\
\text { (Merops viridis) }\end{array}$ & $\begin{array}{l}\text { Resident }- \text { Fairly } \\
\text { Common }\end{array}$ & & 1 & & \\
\hline Muscicapidae & $\begin{array}{l}\text { Pied Fantail } \\
\text { (Rhipidura javanica) }\end{array}$ & Resident- Common & & 2 & 1 & 2 \\
\hline Nectariniidae & $\begin{array}{l}\text { Olive-backed Sunbird } \\
\text { (Nectarinia jugularis) }\end{array}$ & $\begin{array}{l}\text { Resident } \\
\text { 25Common }\end{array}$ & 10 & 15 & 17 & 8 \\
\hline Phasianidae & $\begin{array}{l}\text { Red Jungle Fowl } \\
\text { (Gallus gallus) }\end{array}$ & Resident - Common & & 20 & & 17 \\
\hline Ploceidae & $\begin{array}{l}\text { Eurasian Tree Sparrow } \\
\text { (Passer montanus) }\end{array}$ & Resident- Common & 15 & 40 & 25 & 25 \\
\hline Pycnonotidae & Yellow Vented Bulbul & Resident - Common & 8 & 15 & 12 & 13 \\
\hline
\end{tabular}




\begin{tabular}{|c|c|c|c|c|c|}
\hline & (Pycnonotus goiavier) & & & & \\
\hline Sturnidae & $\begin{array}{l}\text { Asian Glossy Starling } \\
\text { (Aplonis panayensis) }\end{array}$ & Resident - Common & 11 & 13 & 6 \\
\hline Sylviidae & $\begin{array}{l}\text { Lanceolated Warbler } \\
\text { (Locustella ochotensis) }\end{array}$ & Migrant-uncommon & & 2 & \\
\hline
\end{tabular}

Table 2. Diversity index of observation in each sites.

\begin{tabular}{lcccc}
\hline & O 1 & O2 & O3 & O4 \\
\hline Shannon H' Log Base & 0.857 & 1.09 & 0.858 & 0.948 \\
Shannon Hmax & 1 & 1.322 & 1.114 & 1.079 \\
Shannon J' & 0.857 & 0.83 & 0.77 & 0.878 \\
\hline
\end{tabular}

In table 2 above Observation area 2 is highly diverse when compared to among other areas. O2 served as the feeding areas of most birds like the Pacific Swallow (H. tahitica) usually flies in areas where high density of insects especially in wet season (Turner, 1983). The birds belonging to family Nectariinidae, the Olive-backed Sunbird (N. jugularis) also found perching in flowering trees in open and closed canopies said to feeding on not only nectars of the flowering plants but also in small arthropods (Maher, 1996). Some granivores like the Chestnut Munia (L. malacca) and Eurasian Tree Sparrow (P. montanus) often seen grazing on grassland and build its nest in herbaceous plants within the area.

\section{Conclusion, Heading Level-1.}

The distribution and diversity of bird species was affected by the structure of the habitat, the type of food item and the abundance of the food item, and time. Most birds were highly active early morning decreases in mid-afternoon and back to increase in late afternoon. Some birds have wide range of food items which tends to dominant in proportion when compared to selective birds.

\section{Acknowledgement}

The researchers would like to thank Abdel Muamar Disomimba for the assistance in bird sampling.

\section{References}

Barbaro, L., Giffard, B., ..., \& Brockerhoff, E. G. (2014). Bird functional diversity enhances insectivory at forest edges: a transcontinental experiment. Diversity and Distributions, 20(2), 149-159. https://doi.org/10.1111/ddi.12132

Bregman, T. P., Sekercioglu, C. H., \& Tobias, J. A. (2014). Global patterns and predictors of bird species responses to forest fragmentation: Implications for ecosystem function and conservation. Biological Conservation, 169, 372-383.

https://doi.org/10.1016/j.biocon.2013.11.024

Carnivora.com. (2013). Tarictic Hornbill (Penelopides panini). Retrieved from http://carnivoraforum.com/topic/9331639/1/ 


\section{Macrothink}

Journal of Biology and Life Science ISSN 2157-6076 2017, Vol. 8, No. 2

Carpio, G. (2006). Philippine Cuckoo Dove (Macropygia phasianella). Wild Bird Club of the Philipppines. Retrieved from http://www.birdwatch.ph/html/gallery/pcdove.html

Catterall, C. P., Cousin, J. A., Piper, S., \& Johnson, G. (2010). Long-term dynamics of bird diversity in forest and suburb: decay, turnover or homogenization? Diversity and Distributions, 16(4), 559-570. https://doi.org/10.1111/j.1472-4642.2010.00665.x

Cheung, L. (2012). Philippine Swiftlet (Aerodramus mearnsi). The Internet IBC Bird Collection.http://ibc.lynxeds.com/photo/philippine-swiftlet-aerodramus-mearnsi/bird-flight

Gabrielsen, L. (2007). Slender Billed Crow. Mangroverde:World Bird Guide. Retrieved from http://www.mangoverde.com/wbg/picpages/pic189-82-1.html

Google Earth. (2016). http://www.google.com/earth/

Kaufman, B. (2010). Da Wow Experience, Part 4. Retrieved from ornithogpraher.blogspot.com/2010_09_01_archive.html

Kennedy, R. (2000). A guide to the birds of the Philippines. Oxford University Press.

Maher, W. J. (1996). "Nestling food and feeding frequencies of the brown-backed honeyeater Ramsayornis modestus and the yellow-bellied sunbird Nectarinia jugularis in northern Queensland." Emu 96(1), 17-22. https://doi.org/10.1007/BF00153826

McIntyre, N. E. (1995). Effects of forest patch size on avian diversity.Landscape Ecology, 10(2), 85-99. https://doi.org/10.1007/BF00153826

Møller, A. P., Fiedler, W., \& Berthold, P. (2010). Effects of climate change on birds. Oxford University Press.

Tscharntke, T., Sekercioglu, C. H., ..., \& Tylianakis, J. M. (2008). Landscape constraints on functional diversity of birds and insects in tropical agroecosystems. Ecology, 89(4), 944-951. https://doi.org/10.1890/07-0455.1

Turner, Angela K. (1983). "Food selection and the timing of breeding of the Blue-and-White Swallow Notiochelidon cyanoleuca in Venezuela." Ibis, 125(4), 450-462.

https://doi.org/10.1111/j.1474-919X.1983.tb03141.x

Volpato, G. H., Lopes, E. V., ..., \& Anjos, L. D. (2009). The use of the point count method for bird survey in the Atlantic forest. Zoologia (Curitiba), 26(1), 74-78.

https://doi.org/10.1590/S1984-46702009000100012

\section{Copyright Disclaimer}

Copyright for this article is retained by the author(s), with first publication rights granted to the journal.

This is an open-access article distributed under the terms and conditions of the Creative Commons Attribution license (http://creativecommons.org/licenses/by/3.0/). 